\title{
Perencanaan Distribusi Gas LPG 3 kg Menggunakan Metoda Distribution Requirement Planning (DRP) di PT Anugrah Ditamas Lestari
}

\author{
Hendy Suryana ${ }^{1,}$ Umar Faruk ${ }^{2}$, \\ ${ }^{1,2}$ Teknik Industri Universitas Suryakancana \\ Jl. Pasir Gede Raya, Bojongherang, Cianjur, Kec. Cianjur, Jawa Barat \\ hendies.free@gmail.com, acecoilrastafara@gmail.com,
}

Dikirimkan: 10, 2017. Diterima: 12, 2017. Dipublikasikan: 12, 2017.

\begin{abstract}
Abstrac - Gas is a contributing factor in various industrial and household activities. PT Anugrah Ditamas Lestari is one of the $3 \mathrm{~kg}$ LPG gas agent that was established since 2008. The problem that happened in PT Anugrah Ditamas Lestari is that LPG sales will be hampered and can't be done in a timely manner will eventually cause loss. Forecasting Linear Regression starts from January 2015 to December 2016, while the DRP (distribution requirement planning) applied in research in gas agents is to know the needs for each base it can be known from the value of gross requirement. the need for a hilman base in 2016 is 63728 tubes / year, Asep.R 58898 tubes / year, Dedin 59961 tubes / year, Didin 58524 tubes / year, muhyidin 8771 tubes / year, suherman 77919 tubes / year, Haris 60108 tubes / year, Ujang 62964 tube / year, Irfan 54095 tube / year while for the maman base of 56826 tubes / year. As for mengatehui needs and determine the delivery of LPG gas to each base can be seen from the calculation of pland order release, for the Hilman base it needs a gas supply of 63700 tubes / year, while for Dedin 58900 tubes / year, Didin 59800 tubes / year, Muhyidin 8700 tubes / year, Suherman 77800 tubes / year, Haris 59900 tubes / year, Ujang 62500 tubes / year Irfan 53600 tube / year, while for the Maman base needs LPG gas supply of 56800 tubes / year, from the calculation of DRP needs lpg gas most is suherman base as much as 77800 tubes / year.
\end{abstract}

Keywords: linear regression forecasting, DRP (Distribution Requirement Planning) gross requirement and Plannd order release

Abstrak- Gas merupakan faktor penujang dalam berbagai kegiatan industry maupun rumah tangga . PT Anugrah Ditamas Lestari adalah sebagai salah satu agen gas LPG ukuran 3kg yang berdiri sejak tahun 2008. Permasalahan yang terjadi di PT Anugrah Ditamas Lestari ini adalah penjualan gas lpg akan terhambat dan tidak dapat dilakukan secara tepat waktu akhirnya akan menimbulkan kerugian. Peramalan Regresi Linier dimulai dari bulan januari 2015 sampai dengan desember 2016, sedangkan DRP (distribution requirement planning) diterapkan dalam penelitian di agen gas adalah untuk mengetahui kebutuhan untuk masing masing pangkalan hal ini dapat di ketahui dari nilai gross requirement.kebutuhan untuk pangkalan hilman pada tahun 2016 sebesar 63728 tabung/tahun, Asep.R 58898 tabung/tahun, Dedin 59961 tabung/tahun, Didin 58524 tabung/tahun, muhyidin 8771 tabung/tahun, suherman 77919 tabung/tahun, Haris 60108 tabung/tahun, Ujang 62964 tabung/tahun, Irfan 54095 tabung/tahun sedangkan untuk pangkalan maman sebesar 56826 tabung/tahun. Sedangkan untuk mengatehui kebutuhan dan menentukan pengiriman gas LPG ke setiap pangkalan dapat dilihat dari hasil perhitungan dari pland order release, untuk pangkalan hilman membutuhkan persedian gas sebesar 63700 tabung/tahun, sedangkan untuk pangkalan Dedin 58900 tabung/tahun, Didin 59800 tabung/tahun, muhyidin 8700 tabung/tahun, suherman 77800 tabung/tahun, Haris 59900 tabung/tahun, Ujang 62500 tabung/tahun Irfan 53600 tabung/tahun, sedangkan untuk pangkalan maman membutuhkan persediaan gas LPG sebanyak 56800 tabung/tahun, dari hasil perhitungan DRP maka kebutuhan gas LPG terbanyak adalah pangkalan suherman sebanyak 77800 tabung/tahun.

Kata kunci : Distribution Requirment Planning (DRP), Planned order release, regresi linier

\section{PENDAHULUAN}

Masyarakat Indonesia merupakan salah satu masyarakat dunia yang memiliki ketergantungan yang sangat tinggi terhadap bahan bakar minyak (BBM) sangat tinggi baik itu untuk keperluan rumah tangga, transportasi maupun bahan bakar untuk industri yang berjalan di bidang 
manufaktur, sehingga wajar apa bila negara berusaha keras untuk memenuhi kebutuhan warga negaranya yang bersifat primer ini dengan memberikan subsidi terhadap pembelian BBM. Pada tahun 2007 sampai 2010 merupakan tahun dimana pemerintah gencar-gencarnya melakukan sosialisai penggunaan gas liquefied petroleum gas (LPG/lpiji), bagi konsumsi rumah tangga dan industri kecil. Peraturan persediaan republik Indonesia, nomor 104 tahun 2007 tentang penyediaan, pendistribusian dan penempatan harga LPG dan peraturan mentri SDM No 21 tahun 2007 tentang penyelenggaraan penyediaan dan pendistribusian tabung LPG $3 \mathrm{~kg}$, menjadi dasar hukum kebijakan tersebut.

Gas merupakan faktor penunjang dalam berbagai kegiatan industry maupun rumah tangga. Pada perkembangannya, industri ini merupakan slah satu industri yang sangat vital. Semua orang membutuhkan gas baik untuk agrikultur, medis hingga keperluan-keperluan khusus. Kebutuhan akan gas ini sangat vital, oleh karena itu perusahan gas perlu memenuhi kebutuhan konsumen dengan tepat waktu dalam perusahaan industri yang ada. Hal ini diperlukan agar kinerja dan proses bisnis dan pihak-pihak terkait tidak terhambat dengan permasalahan yang terjadi dalam produksi maupun distribusi.

\section{Metodologi Penelitian}

Dalam distribusi produknya. Perusahan harus memiliki perencanaan yang baik agar barang yang diperoduksinya dapat sampai kepada konsumen tepat waktu, dan jumlah perencanaan ini akan membantu perusahaan menghindari dairi kekurangan stok dan mengurangi biaya penyimpanan karena kelebihan stok. Metodologi penelitian digambarkan Gambar 1.

\subsection{Inventarisir Data}

Inventarisir data dilakukan untuk memperoleh suatu data mentah yang layak untuk diolah dengan baik.

Model pemecahan masalah yang digunakan dalam penelitian ini adalah dengan melakukanpengamatan yang berdasarkan tiga variabel yaitu:

\section{$>$ Inventory \\ $>$ Demand \\ $>$ Lot Sie}

\subsection{Jenis Data}

Jenis data yang dibutuhkan dalam penelitian ini terdiri dari dua jenis data yaitu :

a. Data perimer. Data yang dikumpulkan dan diolah sendiri oleh suatu organisasi perusahaan atau perorangan langsung dari objeknya. Data ini diperoleh dari hasil survey dan wawancara langsung.

b. Data skunder, yaitu data yang diperoleh dalam bentuk jadi, dan sudah dikumpulkan atau diolah oleh pihak lainya biasanya dalam bentuk publikasi, data skunder diperoleh dari buku-buku pedoman leteratur jurnal/ laporan penelitian

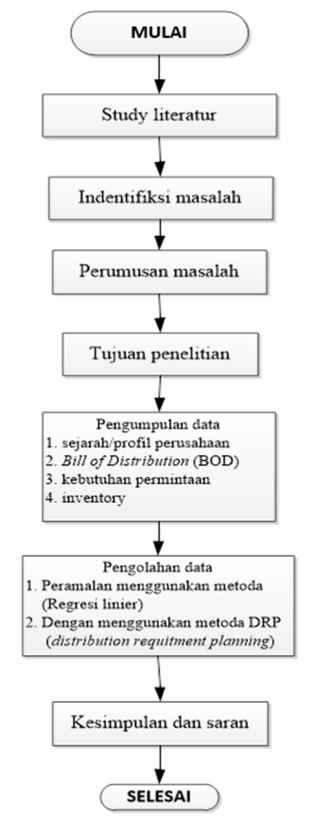

Gambar 1. Metodologi Penelitian

\subsection{Pengolahan Data}

Metoda Peramalan Regresi Linier (Linear Regression Forecasting)

Metoda ini adalah untuk menentukan kebijakan manajemen atas pengiriman barang ke konsumen dimasa yang akan dating. Hal ini diperoleh berdasarkan dari data permintaan masa lalu.

Peramalan merupakan satu masukan terhadap seluruh jenis peencanaan dan pengendalian bisnis (buisnis planning and control), baik untuk di dalam fungsi operasi maupun di luar fungsifungsi operasi [1]. Pemasaran (marketing) menggunakan permalan untuk merencanakan produk, promosi dan penetapan harga, keuangan (finance) menggunakan peramalan sebagai mesukan terhadap perencanaan finansial, peramalan juga sebagai masukan untuk keputusan operasi pada proses desain, perencanaan kapasitas dan persediaan. 


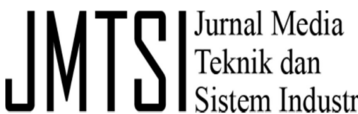

Metoda

DRP

(Distribution

Requirement

Planning)

Model ini digunakan untuk merencanakan pemenuhan kembali persediaan pada semua tingkat jaringan distribusi. Perhitungan perencanaan distribusi dimulai dari tingkat pangkalan sebagai jaringan terakhir dari pendistribusian gas LPG.

Industri memiliki tingkat persaingan yang ketat dalam era pasar bebas, hingga ke tingkat distributor. Distributor dituntut menyalurkan produk dengan baik untuk mencegah kekosongan stok. Konsumen akan merasa puas terhadap pelayanan distributor, jika produk tersebut tiba tepat waktu, tepat jumlah dan tepat mutu. Hal ini mengakibatkan kebijakan untuk pengendalian persediaan produk pada suatu lokasi tertentu sangat penting dilakukan oleh manajemen dalam mengkoordinasikan penjadwalan dan perencanaan distribusi dari bagian pemasaran sehingga keuntungan perusahaan tetap stabil. Sebuah hasil survey dari Amerika Serikat menunjukkan bahwa persentase biaya distribusi sebesar $47 \%$ berasal dari biaya transportasi [2]. Oleh karena itu, perencanaan biaya transportasi sangat perlu diperhatikan oleh perusahaan agar terjadi penghematan dalam anggaran perusahaan. Biaya transportasi yang besar disebabkan oleh pemakaiaan kapasitas bak truk yang belum dioptimalkan. Dengan susunan produk yang tepat maka bak truk dapat diisi lebih banyak produk dan jumlah truk yang dipakai akan berkurang. Metode DRP dapat meminimisasi biaya distribusi perusahaan [3].

Perencanaan dengan metode DRP pada rancangan ini menggunakan software Cargowiz untuk mendapatkan order quantity yang disesuaikan dengan kapasitas optimal bak truk. Diharapkan dengan adanya perencanaan dan penjadwalan, aktivitas distribusi yang baik, keberhasilan dalam pemenuhan permintaan pelanggan akan menjadi lebih optimal dan biaya distribusi dapat ditekan seminimun mungkin. Data-data yang perlu dikumpulkan adalah lead time, service level, project on hand $(\mathrm{POH})$, ukuran bak truk, dan biaya transportasi. Data-data yg telah dikumpulkan kemudian diolahdan dianalisis dengan prosedur yang telah ditentukan. Kerangka pemecahan masalah dalam penelitian ini secara umum digambarkan pada Gambar 2.

\section{HAsil PENELITIAN DAN PEMBAHASAN}

\subsection{Sejarah Singkat Perusahaan}

PT. Anugrah Ditamas Lestari (ADL) adalah sebuah perusahaan penyaluran barang yang berupa gas LPG $3 \mathrm{~kg}$. peusahaan ini berada di Jl. Ra Kusumaningrat Kp. Gunteng Rt/Rw 04/09,
Desa. Bojong, Kec. Karang tengah Kab. Cianjur perusahan ini berdiri sejak tanggal 12 mei 2008. PT. Anugrah Ditamas Lestari ini merupakan pelayan dan penjualan, penyaluran gas LPG ke setiap pangkalan PT Anugrah Ditamas Lestari ini di dirikan atas dasar pengalihan minyak tanah ke gas LPG, pada waktu itu minyak tanah sulit didapatkan oleh masyarakat Indonesia terutama masyarakat Cianjur karena keterbatasannya. Sejak tahun 2008 pemerintah melakukan pemasaran ke setiap daerah Cianjur, setiap harinya PT Anugrah ditamas lestari mengangkut gas LPG dengan kapasitas alat angkut 2 tangki besar dan 1 mobil bak.
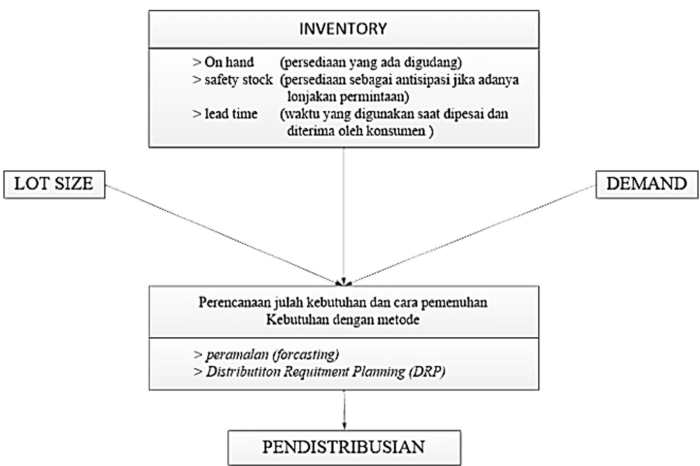

Gambar 2. Kerangka pemecahan masalah

Seiring dengan program pemerintah yang melakukan konvesrsi dari minyak ke gas LPG, kebutuhan dan pasokan gas brukuran $3 \mathrm{~kg}$ semankin meningkat. Agen minyak tanah beralik menjadi agen gas LPG dan tidak semua agen gas atau sub agen merata di suatu wilayah. Sub agen gas LPG merupakan merupakan turunan dari agen yang merupakan penerima pasokan langsung dari pertamina. Dan agenlah yang mendapatkan pasokan dari pertamina untuk menjual dan mendistribusikan gas LPG ke setiap pangkalan yang ada disekitar lokasi agen.

TABEL I

HARGA LPG BERLAKU

\begin{tabular}{|l|l|}
\hline harga ex. PERTAMINA/SPPBE & Rp.12.600 \\
Margin El piji & RP. 1.150 \\
\hline Harga jual ke pangkalan & Rp.13.750 \\
\hline
\end{tabular}

Visi Misi Perusahaan

$>$ Visi dari PT.ANUGRAH DITAMAS LESTARI yaitu :"menjadi perusahaan distributor gas LPG yang bisa bersaing dengan sehat"

> Misi perusahaan kami adalah "menyediakan kebutuhan para langganan atas gas LPG yang berkualitas dan mampu memenuhi pemesanan gas pada waktu yang tepat". 
$\underline{\text { Struktur Organisasi Perusahaan }}$

Adapun bentuk organisasi yang digunakan oleh PT ADL yaitu agen pendistribusian gas LPG $3 \mathrm{~kg}$ yaitu memakai organisasi lini (lini organitation), yaitu suatu bentuk organisasi yang didalamnya terdapat garis wewewnangyang menghubungkan secara langsung antara atasan dengan bawahan, dari pimpinan sampai pada setiap pada jabatan yang terendah dan masing- masing dihubungkan dengan suatu garis wewenang atau garis perintah. Adapun struktur organisasi sebagai berikut :

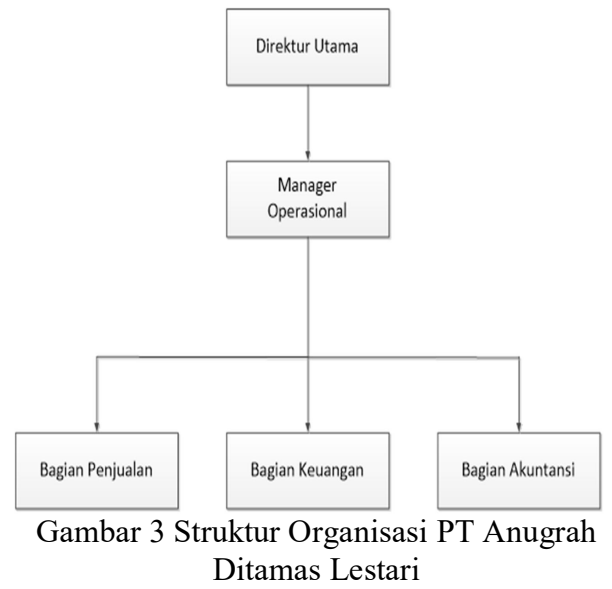

Struktur Distribusi PT ADL

Secara umum wilayah pendistribusian gas LPG ukuran $3 \mathrm{~kg}$ PT. Anugrah Ditamas Lesrari mencakup wilayah kabupaten Cianjur yang tersebar diberbagai kecamatan yang ada di wilayah Cianjur.

Struktur distribusi merupakan fakor penting dalam melakukan distribusi gas, karena dengan struktur distribusi, dan untuk mendistribusikan gas dalam jumlah besar dapat dilakukan dengan jelas dan terarah. Sehingga kemana dan berapa jumlah produk yang hasrus di distribusikan dapat diketahui dengan presisi yang tepat.struktur distribusi, Gambar 4 menunjukan bahwa PT.Anugrah Ditamas Lestari merupakan salah satu agen pendistribusian gas LPG $3 \mathrm{~kg}$. Gas yang di distribusikan oleh PT. Anugrah Ditamas Lestari, diisi oleh pertamina/SPPBE terdekat, kemudian tabung gas yang sudah terisi akan dikembalikan ke agen. Setelah itu gas yang sudah ada di agen akan didistribusikan ke setiap pangkalan. Tabel II menunjukan daftar nama nama pangkalan gas LPG $3 \mathrm{~kg}$ yang didistribusikan oleh PT. Anugrah Ditamas Lestari yang bertempat di kabupaten Cianjur.

\subsection{Safety Stock}

Persediaan pengaman (safety stock) adalah persediaan yang dicadangkan untuk kebutuhan selama menunggu barang datang. Persediaan pengaman juga biasa disebut sebagai persediaan penyangga (buffer stock) atau persediaan besi (iron stock). Persediaan pengaman berfungsi untuk melindungi atau menjaga kemungkinan terjadinya kekurangan barang, misalnya karena penggunaan barang yang lebih besar dari perkiraan semula atau keterlambatan dalam penerimaan barang yang dipesan. Selain itu, berfungsi juga untuk menjamin pelayanan kepada pelanggan terhadap ketidakpastian dalam pengadaan barang.

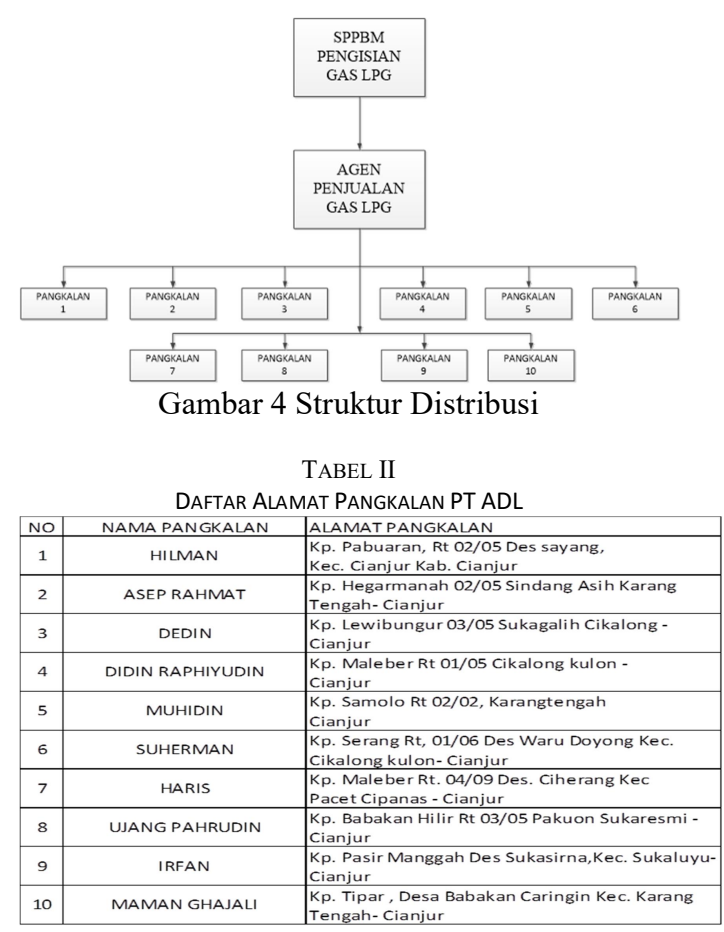

Persediaan pengaman dapat ditentukan langsung dalam jumlah unit tertentu, misalnya 20 unit, atau berdasarkan persentase dari kebutuhan selama menunggu barang datang (waktu tenggang). Hal ini tergantung dari pengalaman perusahaan dalam menghadapi keterlambatan barang yang dipesan atau sering berubah tidaknya perencanaan produksi. Cara lain dalam menentukan besarnya persediaan pengaman ialah dengan pendekatan tingkat pelayanan (service level). Tingkat pelayanan dapat didefinisikan sebagai probabilitas permintaan tidak akan melebihi persediaan (pasokan) selama waktu tenggang. Tingkat pelayanan 95\% menunjukkan bahwa besarnya kemungkinan permintaan tidak akan melebihi persediaan selama waktu tenggang ialah 95\%. Dengan kata lain, resiko terjadinya kekurangan persediaan (stockout risk) hanya 5\%. 


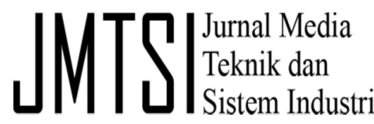

3.3 Persediaan

Persediaan (inventory) adalah suatu istilah umum yang menunjukan sesuatu atau sumberdaya organisasi atau yang disimpan untuk mengantisipasi terhadap pemenuhan permintaan baik internal maupun eksternal [4].

Sistem persediaan adalah serangkaian kebijakan dan pengendalian yang memonitor tingkat persediaan dan menentukan tingkat persediaan yang harus dijaga, kapan persediaan harus disini, dan berapa besar pesanan yang harus dilakukan. Sistem ini bertujuan untuk menetapkan dan menjamin tersedianya sumber daya yang tepat, dalam kuantitas yang tepat dan pada waktu yang tepat atau dengan kata lain system dan model persediaan bertuuan untuk meminimumkan biaya total melalui penentuan, berapa dan kapan pesanan yang akan dilakukan secara optimal

\subsection{Bill OF Distribution (BOD)}

Secara umum bill of distribution (BOD) merupakan rangkaian struktur semua chanel distribusi gas LPG $3 \mathrm{~kg}$, tanpa adanya susunan struktur BOD penempatan system DRP (distribution requirement planning) ternyata tidak bisa dilaksanakan. BOD biasanya ditentukan berdasarkan struktur distribusi dengan memuat informasi nomor dan jenis pangkalan tersebut. Pada BOD ini akan terlihat atau level distribusi dan nama chanelnya seperti pada tabel III di bawah ini.

TABEL III

DAFTAR BOD PT ADL

\begin{tabular}{|c|c|l|}
\hline NO & NO Lokasi & \multicolumn{1}{|c|}{ Nama Pangkalan } \\
\hline 2 & 11 & PT. Anugrah Ditamas Lestari \\
\hline 1 & 1 & pangkalan hilman \\
\hline 1 & 2 & pangkalan asep rahmat \\
\hline 1 & 3 & pangkalan dedin \\
\hline 1 & 4 & pangkalan didin raphiyudin \\
\hline 1 & 5 & pangkalan muhidin \\
\hline 1 & 6 & pangklan suherman \\
\hline 1 & 7 & pangkalan haris \\
\hline 1 & 8 & pangklan ujang pahrudin \\
\hline 1 & 9 & pangkalan irfan \\
\hline 1 & 10 & pangkalan maman ghajali \\
\hline
\end{tabular}

\subsection{Permintaan (Demand)}

Dalam melakukan penelitian ini tentunya diperlukan data historis permintaan (historical data) terhadap gas LPG $3 \mathrm{~kg}$. berikut ini disajikan data permintaan gas LPG $3 \mathrm{~kg}$ untuk semua pangkalan di agen PT. Anugrah Ditamas Lestari. Data ini merupakan data permintaan dari 12 bulan sebelum nya untuk pangkalan Hilman pada tahun 2015-2016 sebesar 44898 tabung/tahun; Asep R, sebear 35232; Dedin 41884; Didin 58739; Muhyidin 9065; Suherman
37285; Haris 40656; Ujang 35451; Irfan 54470; dan Maman 51912 tabung/tahun

\subsection{Inventori}

Data inventori, menckup data on hand, safety stock, lead time, dan lot size masing masing pangkalan distribusi gas LPG $3 \mathrm{~kg}$. rekapitulasi data inventory status tersebut dapat di lihat pada tabel IV.

TABEL IV

DAFTAR INVETORI PT ADL

\begin{tabular}{|r|l|c|c|c|c|}
\hline No & \multicolumn{1}{|c|}{ Nama pangkalan } & lot size & lead time & safety stock & on hand \\
\hline 1 & pangkalan hilman & 100 & 1 & 50 & 130 \\
\hline 2 & pangkalan asep rahmat & 100 & 1 & 50 & 120 \\
\hline 3 & pangkalan dedin & 100 & 1 & 50 & 250 \\
\hline 4 & pangkalan didin raphiyudin & 100 & 1 & 50 & 500 \\
\hline 5 & pangkalan muhidin & 100 & 1 & 50 & 200 \\
\hline 6 & pangklan suherman & 100 & 1 & 50 & 200 \\
\hline 7 & pangkalan haris & 100 & 1 & 50 & 300 \\
\hline 8 & pangklan ujang pahrudin & 100 & 1 & 50 & 560 \\
\hline 9 & pangkalan iffan & 100 & 1 & 50 & 560 \\
\hline 10 & pangkalan maman ghajali & 100 & 1 & 50 & 158 \\
\hline 11 & PT. Anugrah Ditamas Lestari & 560 & 1 & 560 & 2800 \\
\hline
\end{tabular}

\subsection{Peramalan Regresi Linier}

Berdasarkan data permintaan dari pangkalan yang telah dikumpulkan diatas, maka dilakukanlah langkah peramalan dengan metoda peramalan yang ada maka dari pengolahan peramalan akan menghasilakan nilai $\operatorname{MSE}($ mean square error) dari perhitungan peramalan.

Dari hasil peramalan yang telah dilakukan tersebut maka akan muncul nilai MSE yang paling tekecil dari langkah perhitungan peramalan regresi linier. Dengan metoda peramalan regresi linier MSE terkecil akan dipilih sebagai metoda untuk melakukan langkah peramalan berikutnya dari data permintaan yang ada. Hasil peramalan menggunakan metoda peramalan regresi linier.

Dari hasil peramalan Regrsi Linier untuk pangkalan Hilman untuk 1 tahun ke depan sebesar 63728; Asep R. 58898; Dedin 59962; Didin 58522; Muhyidin 8769; Suherman7792; Haris 60108; Ujang 62963; Irfan 540295; dan Maman 56826 tabung/tahun.

\subsection{Distribution Requirement Planning (DRP)}

Perhitungan DRP (Distribution Requirement Planning) diantaranya adalah untuk menyelesaikan masalah distribusi yang dihadapi oleh perusahaan, berikut langkah langkah perhitungan DRP yang harus dilakukan.

1. Pangkalan Hilman

- Perhitungan Gross requirement (GR) diperoleh dari hasil peramalan yang sebelumnya dilakukan dengaan menggunakan peramalan regresi linier. 
- Menentukan Project Available Balance (PABI)

$$
\begin{aligned}
& \operatorname{PABI}_{(1)}=\text { past due }-G R_{(1)} \ldots \ldots . .(\text { periode awal }) \\
& \operatorname{PABI}_{(\text {januari-13) }}=130-4591=-4461 \\
& \operatorname{PABI}_{(\mathrm{t})}=\operatorname{PAB~II}(t-1) \\
& \operatorname{PABI}_{(\text {january }-13)}=13 R_{(t)} \cdots \ldots . .(\text { periode selanjutnya })
\end{aligned}
$$

- Menentukan Net Requirement (NR)

$$
\begin{aligned}
& \mathrm{NR}_{(t)}=S S-\left(\text { past due }-G R_{(t)}\right) \\
& \mathrm{NR}_{(\text {januari-13) }}=50-(130-4591)=4511 \\
& \mathrm{NR}_{(\mathrm{t})}=\mathrm{SS}-\left(\mathrm{PABII}_{(\mathrm{t}-1)}-G R_{(t)}\right) \\
& \mathrm{NR}_{(\text {january-13) }}=139-4722=4643
\end{aligned}
$$

- $\quad$ Menentukan Planned Order Receipt (PORc) Untuk menentukan PORc adalah dengan memperhatikan kelipatan terkecil dari lot size yang dapat memenuhi net requirement.

$$
\begin{aligned}
& \mathrm{NR}_{(\text {januari-13) }}=4511+\text { lot size }=100 \\
& \text { maka,PORc }_{(\text {januari-13) }}=4600
\end{aligned}
$$

- Menentukan Planned order Release (PORL) Jumlah PORL dapat ditentukan dengan menempatkan PORc sesuai dengan lead time yang ada. Karena priode waktu yang digunakan bulan maka Lead time $=1$ hari tidak diperhitungkan (tidak berpengaruh). sebab masih ada dalam bulan yang bersangkutan.

Lead Time $=1$

PORc $($ januari-13) $=4600$

maka, PORL $=4600$ (pada bulan januari 2016)

\section{- Menentukan PAB II}

$$
\begin{aligned}
& \operatorname{PAB~II}_{(1)}=\text { past } d u e-G R+P O R c \ldots \ldots . .(\text { periode awal }) \\
& \operatorname{PAB~II}_{(\text {januari }-13)}=130-4591+4600=139 \\
& \operatorname{PAB~II}_{(\mathrm{t})}=\operatorname{PAB~II}_{(t-1)}-G R_{(t)}+P O R c \ldots \ldots .(\text { periode selanjutny a }) \\
& \operatorname{PAB~II}_{(\text {january }-13)}=139-4722+4700=116
\end{aligned}
$$

Perhitungan DRP (distribution requirement planning) untuk pangkalan selanjutnya dapat dilakukan dengan rumus yang sama seperti perhitungan pangkalan hilman. Dengan perhitungan yang sama. Maka dapat dilihat hasil perhitungan DRP yang terlihat pada tabel berikut ini

Dengan mengetahui kebutuhan Gas LPG ukuran $3 \mathrm{~kg}$ untuk setiap pangkalan, maka PT Anugrah Ditamas Lestari dapat menentukan kepastian waktu pemesanan yang terbaik untuk mengetahui kebutuhan, untuk melihat waktu dan jumlah pemesanan dapat dilihat dari planned order release (PORL). Maka jumlah kebutuhan yang paling banyak adalah pangkalan Suherman yaitu sebanyak 77800 tabung hal ini disebabkan karena pangkalan Suherman berdekatan dengan pasar, pemukiman penduduk dan waduk maleber, sehingga penjualan Gas LPG ukuran $3 \mathrm{~kg}$ di daerah tersebut sangat tinggi.

TABEL V

\begin{tabular}{|l|c|}
\multicolumn{2}{|c|}{ HASIL PERHITUNGAN PORL } \\
\hline HANGIL PORL \\
\hline HILMAN & 63700 \\
\hline ASEP R & 58900 \\
\hline DEDIN & 59800 \\
\hline DIDIN & 58100 \\
\hline MUHYIDIN & 8700 \\
\hline SUHERMAN & 77800 \\
\hline HARIS & 59900 \\
\hline UJANG & 62500 \\
\hline IRFAN & 53600 \\
\hline MAMAN & 56800 \\
\hline
\end{tabular}

\section{KESIMPULAN DAN SARAN}

\subsection{Kesimpulan}

Berdasarkan hasil penelitian mengenai pemecahan masalah distribusi dengan menggunakan metoda DRP (Distribusi Requitmen Planning) ini, maka diperoleh suatu kesimpulan sebagai berikut :

- Dengan diketahuinya jumlah Gross Requirement yang terlihat pada BAB IV di tabel 4.26 sampai dengan 4.35 unuk masingmasing pangkalan, maka PT. Anugrah Ditamas Lestari dapat mengetahui dengan jelas berapa jumlah kebutuhan Gas LPG 3 kg yang akan dibutuhkan oleh pangkalanpangkalan untuk 12 bulan ke depan.

- Dengan mengetahui jumlah planned Order Release pada BAB IV di tabel 4.26 dampai dengan 4.35 untuk masing-masing pangkalan, maka PT. Anugrah Ditamas Lestari dapat memesan Gas LPG ukuran 3 kg ke tingkat diatasnya yaitu SPBE sebagai center supply. Sehingga pemenuhan kebutuhan untuk pangkalan dapat terpenuhi pada periode bulan yang sedang berjalan. 
- Dari hasil perhitungan DRP (Distribusition Requitmen Planning) akan dapat mengetahui jumlah dan waktu pemesanan dengan tepat. Maka PT. Anugrah Ditamas Lestari, dapat membuat rencana pemenuhan kebutuhan gas LPG untuk setiap pangkalan dengan baik. Sehingga pada akhirnya akan terpenuhinya kebutuhan gas LPG untuk setiap pangkalan.

4.2 Saran

Berdasarkan hasil penelitian, dapat diberikan saran sebagai bahan pertimbangan PT ADL adalah sebagai berikut:

- Untuk PT. Anugrah Ditamas Lestari maka bisa menggunakan teknik peramalan dengan menggunakan metoda regresi linier

- Untuk pemecahan kebutuhan PT. Anugrah Ditamas Lestari dapat menggunakan metoda DRP. dengan meninjau kembali factorfaktor lainya, karena hal ini dapat memberikan dampak yang kompleks terhadap kelangsungan perusahaan

\section{REFRENSI}

[1] Schroeder, Roger G. "Operations Management: Contemporary Concepts and Cases, International Edition", Mc Graw-Hill Companies, Inc., Boston.2000

[2] Stewart, W. M. "Distribution: The Current State And Future Trends", Retail and Distribution Management, Vol. 6 Issue: 6, pp.63-65, https://doi.org/10.1108/eb017973. 1978

[3] Martin. A. J. "DRP: Distribution Resource Planning - The Gateway to True Quick Response and Continuous Replenishment, Revised Edition. John Wiley \& Sons, Inc. New York. 1995

[4] Handoko, T. H. "Dasar-dasar Manajemen Produksi dan Operasi, Edisi 1", BPFE, Yogyakarta. 2000 